\title{
Magnesium deficiency with high calcium-to-magnesium ratio promotes a metastatic phenotype in the CT26 colon cancer cell line
}

Gopal Kumar ${ }^{1}$, Prodyot K. Chatterjee ${ }^{2}$, Swati Madankumar ${ }^{2}$, Syed F. Mehdi ${ }^{2}$, Xiangying Xue ${ }^{2}$, Christine N. Metz ${ }^{1,2,3}$

${ }^{1}$ Elmezzi Graduate School of Molecular Medicine, Northwell Health, 350 Community Drive, Manhasset, 11030, New York, United States; ${ }^{2}$ Institute of Molecular Medicine, Feinstein Institutes for Medical Research, Northwell Health, 350 Community Drive, Manhasset, 11030, New York, United States; ${ }^{3}$ Donald and Barbara Zucker School of Medicine at Hofstral Northwell, 500 Hofstra Blvd, Hempstead, 11549, New York, United States

Correspondence : Metz C, Institute for Molecular Medicine, The Feinstein Institute for Medical Research, 350 Community Drive, Manhasset, NY 11030

$<$ cmetz@northwell.edu>

\begin{abstract}
Magnesium ( $\mathrm{Mg}$ ) plays important roles in maintaining genomic stability and cellular redox. Mg also serves as nature's physiological calcium (Ca) channel antagonist, controlling intracellular Ca entry. Because $\mathrm{Ca}$ is the most important second messenger, its intracellular concentration is tightly regulated. Excess intracellular Ca can activate aberrant signaling pathways leading to the acquisition of pathological characteristics and cell injury. Several epidemiological studies have linked $\mathrm{Mg}$ deficiency $(\mathrm{MgD})$ and increased $\mathrm{Ca}: \mathrm{Mg}$ ratios with higher incidences of colon cancer and increased mortality. While it is estimated that less than $50 \%$ of the US population consumes the recommended daily allowance for $\mathrm{Mg}$, Ca supplementation is widespread. Therefore, we studied the effect of $\mathrm{MgD}$, with variable $\mathrm{Ca}: \mathrm{Mg}$ ratios on cellular oxidative stress, cell migration, calpain activity, and associated signaling pathways using the CT26 colon cancer cell line. $\mathrm{MgD}$ (with $\mathrm{Ca}: \mathrm{Mg}$ ratios >1) elevated intracellular Ca levels, calpain activity and TRPM7 expression, as well as oxidative stress and cell migration, consistent with observed degradation of fulllength E-cadherin, $\beta$-catenin, and $\mathrm{N}$-terminal FAK. MgD was accompanied by enhanced degradation of $\mathrm{I} \kappa \mathrm{B} \alpha$ and the transactivation domain containing the $\mathrm{C}$ terminus of NF- $\mathrm{KB}$ p65 (RelA). MgD-exposed CT26 cells exhibited increased p53 degradation and aneuploidy, markers of genomic instability. By contrast, these pathological changes were not observed when CT26 were cultured under MgD conditions where the Ca:Mg ratio was kept at 1 . Together, these data support that exposure of colon cancer cells to $\mathrm{MgD}$ with physiological Ca concentrations (or increasing $\mathrm{Ca}: \mathrm{Mg}$ ratios) leads to the acquisition of a more aggressive, metastatic phenotype.
\end{abstract}

Key words: calcium-to-magnesium ratio, calpain activity, cell migration, CT26 cell line, genomic instability, magnesium deficiency, focal adhesion kinase, oxidative stress 


\section{Introduction}

Magnesium (Mg) and calcium (Ca) share several chemical properties. In biological systems, their functions are often antagonistic due to differences in the number of hydration shells surrounding each ion and their solubility constants [1]. $\mathrm{Mg}$ is more soluble than $\mathrm{Ca}$ and is the most abundant intracellular divalent cation. $\mathrm{Ca}$ is excluded from the intracellular environment and several pumps have evolved to either sequester $\mathrm{Ca}$ in specialized intracellular compartments or pump it outside the cells, as it can precipitate phosphate and organic anions, damaging cellular macromolecules [2]. Later in the course of evolution, this difference between intracellular and extracellular concentrations of $\mathrm{Ca}\left(10^{4} \mathrm{X}\right.$ gradient) made it one of the most important second messengers for intracellular communication and signal transduction [3].

Like $\mathrm{Ca}, \mathrm{Mg}$ participates in a wide range of biological functions. It acts as an essential cofactor in more than 300 enzymatic reactions in the body [3-5] and serves as a physiological $\mathrm{Ca}$ channel antagonist [6]. As such, $\mathrm{Mg}$ maintains or regulates cellular antioxidant status, cellular energetics, genomic stability, and immuno-inflammatory responses [7]. While the recommended dietary allowance (RDA) for $\mathrm{Mg}$ is $300-400 \mathrm{mg}$ per day, it has been estimated that less than $50 \%$ of the U.S. population consumes the RDA for $\mathrm{Mg}$ [8] and certain populations (e.g. elderly, diabetics, and critically ill patients) are at increased risk [9]. As previously described by Castiglioni and Maier, because Mg participates in numerous metabolic and redox processes, it is not surprising that $\mathrm{Mg}$ contributes to cell growth and survival, and Mg deficiency may contribute to cancer initiation and progression [10].

$\mathrm{Ca}$ mediates numerous biological functions by directly binding to intracellular target proteins or by stimulating $\mathrm{Ca}$ sensors that respond to changing $\mathrm{Ca}$ concentrations by activating downstream responses such as calpains, a Ca2+-dependent caspase [11]. $\mathrm{Mg}$ regulates intracellular $\mathrm{Ca}$ entry due to its larger size in aqueous environments [1]. In order to cross ion channels, ions must shed their hydration shells in an energy-consuming process. $\mathrm{Mg}$ with two layers of hydration shells (making it 400X larger than its dehydrated form) is larger than $\mathrm{Ca}$, which has only one layer (making it 25X larger than its dehydrated form) and thus, extracellular $\mathrm{Mg}$ is nature's physiological $\mathrm{Ca}$ channel antagonist by acting as a gate (figure $1 A$ ). Increases in intracellular $\mathrm{Ca}$ concentrations can activate various signaling pathways that promote cell growth, dedifferentiation, survival, angiogenesis, migration and invasion, oxidative stress, and genomic instability [1]. These processes, when sustained or dysregulated, may lead to acquisition of the hallmarks of cancer [12].

Cancer is the second most common cause of death worldwide and the incidence of cancer is increasing [13]. Colon cancer is the second most common cancer in women and third most common cancer in men [13]. In the US despite widespread colon cancer screening, it is the third leading cause of cancer deaths [14]. High rates of tumor recurrences and metastasis contribute to its high mortality rates. Improved understanding of factors that promote tumor progression and metastasis are warranted as low-grade primary tumors are amenable to surgical resection and these patients have better prognosis and survival.

Several epidemiological studies have linked $\mathrm{Mg}$ deficiency (MgD) with high Ca:Mg intake ratios to a higher incidence of colon cancer and mortality $[15,16]$. In addition, higher $\mathrm{Ca}: \mathrm{Mg}$ ratios promote the proliferation of prostate cancer cells and are associated with highly aggressive prostate cancer [17-19]. Similarly, an inverse association between total $\mathrm{Mg}$ intake and all-cause mortality was reported in older women with breast cancer and this was stronger among women with high $\mathrm{Ca}: \mathrm{Mg}$ intake ratios [20]. While most Americans do not consume the RDA for $\mathrm{Mg}$ [8], calcium supplementation is prevalent, especially among the elderly [21]. Therefore, we investigated the effect of $\mathrm{MgD}$ with various $\mathrm{Ca}: \mathrm{Mg}$ ratios on cellular oxidative stress, intracellular Ca levels, calpain activity, markers of genomic instability and cell migration, as well as signaling pathways related to these processes using the well-characterized CT26 colon cancer cell line, which shares numerous molecular characteristics with aggressive and undifferentiated human colon carcinoma cells. 


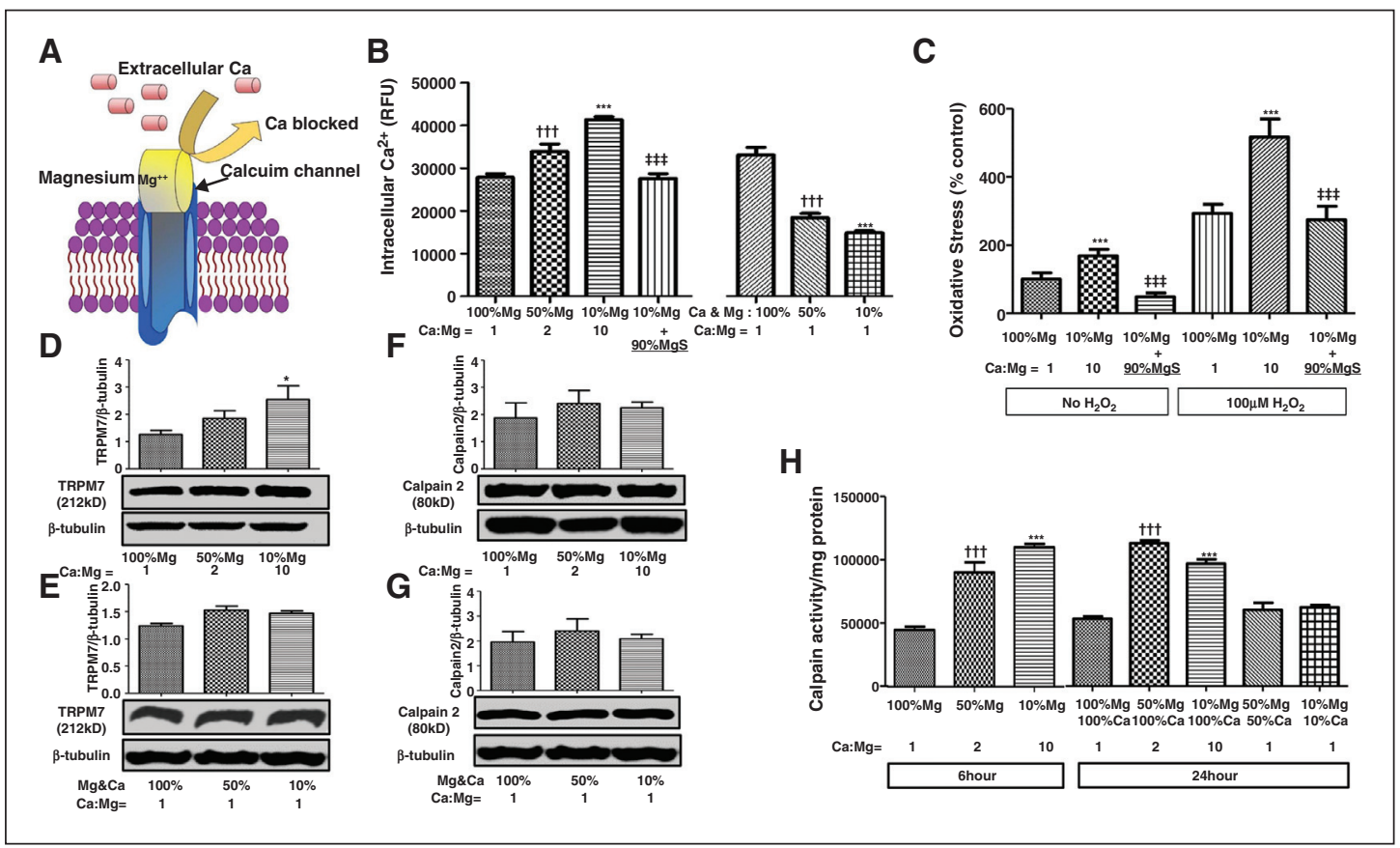

Figure 1. Mg status regulates intracellular calcium levels, oxidative stress, TRPM7 expression, and calpain activity, but not calpain 2 protein expression in CT26 colon cancer cells.

Schematic of Mg blocking intracellular Ca entry through Ca channels (A). CT26 cells were grown under various conditions for $48 \mathrm{~h}$ : $100 \% \mathrm{Mg}$ media, $50 \% \mathrm{Mg}$ media, $10 \% \mathrm{Mg}$ media with $100 \% \mathrm{Ca}$ (i.e. varying Ca: $\mathrm{Mg}$ ratios) or with varying Ca levels $(100 \% \mathrm{Mg} / 100 \% \mathrm{Ca}, 50 \% \mathrm{Mg} / 50 \% \mathrm{Ca}, 10 \% \mathrm{Mg} / 10 \% \mathrm{Ca}$, i.e. keeping Ca:Mg ratio at 1$)$, as indicated $(B, C, D, F)$. In addition, CT26 cells were grown in $10 \% \mathrm{Mg}$ media followed by $90 \% \mathrm{Mg}$ supplementation $(\mathrm{MgS})(10 \% \mathrm{Mg}+90 \% \mathrm{Mg}$ or $\mathrm{MgD} / \mathrm{MgS})$ for $48 \mathrm{~h}(B, C)$. See Methods for details. (B) Intracellular $\mathrm{Ca}$ concentrations were analyzed using the intracellular $\mathrm{Ca}$ indicator Fluo-4, AM, as described in the Methods ( $n=6$ per condition). Data are shown as mean relative fluorescence units $(\mathrm{RFU})( \pm \mathrm{SD})$. (C) Oxidative stress $\left( \pm \mathrm{H}_{2} \mathrm{O}_{2}\right.$ stimulation, $\left.100 \mu \mathrm{M}\right)$ was determined using the DCFH-DA assay, as described in the Methods ( $\mathrm{n}=6$ per condition). Data are shown as mean percent control-oxidative stress $( \pm \mathrm{SD})$. CT26 expression of TRPM7 and $\beta$-tubulin proteins $(D-E)$ and calpain 2 and $\beta$-tubulin proteins $(F-G)$ were assessed by western blotting; representative western blots are shown with quantitation of western blots shown above (mean $\pm \mathrm{SD}$; ( $\mathrm{n}=4-6$ per condition). (H) Cell-associated calpain activity levels were assessed after treating CT26 cells with $100 \% \mathrm{Mg}, 50 \% \mathrm{Mg}$, or $10 \% \mathrm{Mg}$ with $100 \% \mathrm{Ca}$ or $50 \% \mathrm{Mg} / 50 \% \mathrm{Ca}$ and $10 \% \mathrm{Mg} / 10 \% \mathrm{Ca}$ for $6 \mathrm{~h}$ or $24 \mathrm{~h}$, as indicated. Data are shown as mean $( \pm \mathrm{SD})$ relative calpain activity corrected for cell protein ( $\mathrm{n}=4$ per condition). $* * *=\mathrm{p}<0.001$ vs. $100 \% \mathrm{Mg} ; \dagger \dagger \dagger=\mathrm{p}<0.001$ vs. $100 \% \mathrm{Mg} ; \dagger \dagger \dagger=\mathrm{p}<0.001$ vs. $10 \% \mathrm{Mg} . *=\mathrm{p}<0.05$ vs. $100 \% \mathrm{Mg}$.

\section{Methods and materials}

\section{Cell lines, antibodies, and reagents}

The CT26.WT (CT26) cell line (derived from $\mathrm{N}$-nitroso-N-methylurethane (NNMU)-induced, undifferentiated mouse colon carcinoma [female]), the HCT116 cell line (human colorectal carcinoma [epithelial] [male]), and the MCF7 cell line (human breast adenocarcinoma (epithelial) derived from a metastatic site [female]) were purchased from ATCC (Manassas, VA, USA). The A2780 human ovarian carcinoma cell line (epithelial [female]) was obtained from T.C. Hamilton (Fox Chase Cancer Center, Philadelphia, PA, USA). Antibodies: FAK (rabbit antimouse), I $\mathrm{B} \alpha$ (mouse anti-mouse), NF- $\mathrm{kB}$ (p65) (rabbit anti-mouse), E-cadherin (rabbit anti- 
mouse), $\beta$-catenin (rabbit anti-mouse), p53 (mouse anti-mouse), calpain 2 (rabbit antimouse), and $\beta$-tubulin (rabbit anti-mouse) were purchased from Cell Signaling Technology (Danvers, MA, USA). The TRPM7 (rabbit anti-mouse) antibody was purchased from Alomone Labs (Jerusalem, Israel). $\mathrm{MgSO}_{4}$ (anhydrous) was purchased from MP Biomedicals (Irvine, CA, USA). Fluo-4, AM, and 2',7'-Dichlorodihydrofluorescein diacetate (DCFH-DA) were purchased from Molecular Probes/Invitrogen (Carlsbad, CA, USA). 1X MEM (Mg- and Ca-free) media (Cat\# MT15015CV) was purchased from Corning (New York, USA). Fetal bovine serum (FBS) containing approximately $20 \mu \mathrm{g} / \mathrm{ml} \mathrm{Mg}$ was purchased from Atlantic Biologicals/Bio-Techne (Minneapolis, $\mathrm{MN}$ ); note: $10 \%$ FBS-containing media contained approximately $2 \mu \mathrm{g} / \mathrm{ml}$ or $<0.1 \mathrm{mM} \mathrm{Mg}$. $\mathrm{CaCl}_{2}$ was purchased from Ricca Chemical Company (Arlington, TX, USA).

\section{CT26 culture conditions for experimental studies}

For experiments with varying $\mathrm{Ca}: \mathrm{Mg}$ ratios, CT26 cells were plated in 1X MEM media containing 10\%FBS, Pen/Strep/glutamine (PSQ), nonessential amino acids (NEAA), Ca $(100 \% / 1.35 \mathrm{mM})$ as $\mathrm{CaCl}_{2}$, and either $100 \% \mathrm{Mg}$ $(1.35 \mathrm{mM}), 50 \% \mathrm{Mg}(0.675 \mathrm{mM})$, or $10 \% \mathrm{Mg}$ $(0.135 \mathrm{mM})$ as $\mathrm{MgSO}_{4}$. For the $\mathrm{Mg}$ supplementation experiments, CT26 cells were first grown in $10 \% \mathrm{Mg}(0.135 \mathrm{mM})$, as described above, for $24 \mathrm{~h}$ to mimic $\mathrm{Mg}$ deficiency and after $24 \mathrm{~h}$, cells were supplemented with $90 \% \mathrm{Mg}(1.215 \mathrm{mM})$ to simulate $\mathrm{Mg}$ replacement after deficiency $(\mathrm{Mg}$ supplementation, $\mathrm{MgS}, 100 \%$ final). Cells were harvested and analyzed as indicated below. The $100 \%$ values reflect $\mathrm{Mg}$ and $\mathrm{Ca}$ concentrations in mouse serum (CT26 cells are a mouse cell line) [22]. For experiments where the $\mathrm{Ca}: \mathrm{Mg}$ ratio was kept at 1, CT26 cells were grown in 1X MEM media containing $10 \% \mathrm{FBS}$, PSQ, NEAA, and either $100 \% \mathrm{Ca} \quad(1.35 \mathrm{mM})$ and $100 \% \mathrm{Mg}$ $(1.35 \mathrm{mM}), 50 \% \mathrm{Ca}(0.675 \mathrm{mM})$ and $50 \% \mathrm{Mg}$ $(0.675 \mathrm{mM})$, or $10 \% \mathrm{Ca}(0.135 \mathrm{mM})$ and $10 \% \mathrm{Mg}$ (0.135 mM), as $\mathrm{CaCl}_{2}$ and $\mathrm{MgSO}_{4}$, respectively.

\section{Analysis of protein markers by western blotting}

CT26 cells were harvested $6 \mathrm{~h}, 12 \mathrm{~h}, 18 \mathrm{~h}, 24 \mathrm{~h}$, and/or $48 \mathrm{~h}$ after plating in $100 \% \mathrm{Mg}, 50 \% \mathrm{Mg}$, or $10 \% \mathrm{Mg}$ media (with $100 \% \mathrm{Ca}$ or varying $\mathrm{Ca}$ concentrations) or after $\mathrm{Mg}$ supplementation after $\mathrm{MgD}(\mathrm{MgS} / \mathrm{MgD})$, as described above. CT26 cell pellets were homogenized in lysis buffer (Tris-buffered saline, $\mathrm{pH} \quad 7.3$ containing $0.25 \%$ Triton X-100 and protease and phosphatase inhibitor cocktail); protein concentrations were measured using the Bio-Rad Protein Assay (Bio-Rad, Hercules, CA, USA). Proteins $(50 \mu \mathrm{g} /$ lane) were separated by NuPAGE electrophoresis under reducing conditions (Invitrogen, Carlsbad, CA, USA), according to the manufacturer's directions and then transferred to PVDF membranes (Millipore, Billerica, MA, USA). After blocking for $1 \mathrm{~h}$, the membranes were incubated with each primary antibody (FAK, I $\mathrm{B} \alpha, \mathrm{NF}-\kappa \mathrm{B}$ (p65), E-cadherin, $\beta$-catenin, p53, calpain 2 , and $\beta$-tubulin) overnight at $4{ }^{\circ} \mathrm{C}$ (one antibody at a time and according to the manufacturer's directions). After washing, the blots were then incubated with the appropriate HRP-linked secondary antibody, anti-rabbit or anti-mouse IgG (Cell Signaling, according to the manufacturer's guidelines) for $2 \mathrm{~h}$ at room temperature and washed. Blots were developed using the Clarity ECL reagent (Bio-Rad) and assessed on the ChemiDoc MP Imaging System (Bio-Rad) using the ImageLab Software. A representative image is shown for each set of proteins (FAK, I $\kappa \mathrm{B} \alpha, \mathrm{NF}-\kappa \mathrm{B}$ (p65), E-cadherin, $\beta$-catenin, p53, calpain 2, and TRPM7). Blots were stripped with ReBlot Plus (Millipore) and reprobed with various primary antibodies and secondary antibodies (described above). Band loading was confirmed using $\beta$-tubulin protein; quantitation was determined using Image J Software (NIH). Data from blots are presented as ratios of each protein to total protein (mean $\pm \mathrm{SD})$.

\section{Determination of intracellular calcium concentrations}

Forty-eight hours after plating in $100 \% \mathrm{Mg}$, $50 \% \mathrm{Mg}$, or $10 \% \mathrm{Mg}$ media $( \pm \mathrm{MgS})$ with $100 \% \mathrm{Ca}$ (for increasing $\mathrm{Ca}: \mathrm{Mg}$ ratios) or varying Ca concentrations (keeping $\mathrm{Ca}: \mathrm{Mg}$ ratio at 1 ), CT26 cells were washed with $\mathrm{Mg}$ and $\mathrm{Ca}$-free HBSS and then were incubated with Fluo-4-AM (dissolved with DMSO; Molecular Probes/Invitrogen) and pluronic acid for $0.5 \mathrm{~h}$ at $37^{\circ} \mathrm{C}$, followed by $0.5 \mathrm{~h}$ at room temperature. The cells were then harvested, washed with HBSS, resuspended at $1 \times 10^{6} \mathrm{cells} / \mathrm{ml}$, and plated in 
96-well plates $(100 \mu \mathrm{l} /$ well). Intracellular $\mathrm{Ca}$ concentrations were measured with the Genios Pro Fluorescence plate reader (Tecan) at an excitation wavelength of $485 \mathrm{~nm}$ and emission wavelength of $535 \mathrm{~nm}$. Data were collected as relative fluorescence unit (RFU) (mean $\pm \mathrm{SD})$.

\section{Assessment of oxidative stress using the DCFH-DA assay}

CT26 cells were harvested $48 \mathrm{~h}$ after plating in either $100 \% \mathrm{Mg}$ or $10 \% \mathrm{Mg}( \pm 90 \% \mathrm{Mg}, \mathrm{MgS}$ post-MgD) with $100 \% \mathrm{Ca}$ (to mimic increasing Ca: $\mathrm{Mg}$ ratios), washed with $\mathrm{Mg}$ and Ca-free HBSS, resuspended at $1 \times 10^{6} \mathrm{cell} / \mathrm{s} / \mathrm{ml}$ in HBSS, and labeled with DCFH-DA $(20 \mu \mathrm{M})$ for $20 \mathrm{~min}$. Labeled cells were washed, treated with vehicle or $\mathrm{H}_{2} \mathrm{O}_{2}(100 \mu \mathrm{M})$, and analyzed for oxidative stress $0.5 \mathrm{~h}$ later in a quantitative manner using the Victor3 fluorescence plate reader (PerkinElmer) at an excitation wavelength of $485 \mathrm{~nm}$ and emission wavelength of $535 \mathrm{~nm}$. This assay measures the conversion of nonfluorescent DCFH-DA into fluorescent dichlorofluorescein (DCF) by ROS intermediates [23]. Data are presented as percent control oxidative stress (mean $\pm \mathrm{SD}$ ).

\section{Determination of cell-associated calpain activity}

Cell-associated calpain activity was measured using a fluorometric-based Calpain activity assay kit (BioVision, Inc., Milpitas, CA), according to the manufacturer's guidelines and as previously described [24]. Briefly, CT26, A2780, HCT116, and MCF7 cells were plated in 1X MEM media containing 10\% FBS, PSQ, NEAA, and either $100 \% \mathrm{Mg}, 50 \% \mathrm{Mg}$ or $10 \% \mathrm{Mg}$ with $100 \% \mathrm{Ca}$ (to mimic increasing Ca: $\mathrm{Mg}$ ratios) or $50 \% \mathrm{Mg} / 50 \% \mathrm{Ca}$ and $10 \% \mathrm{Mg} / 10 \% \mathrm{Ca}$ (for $\mathrm{Ca}$ : $\mathrm{Mg}$ ratios $=1$ ), as indicated. After $6 \mathrm{~h}$ or $24 \mathrm{~h}$ (as indicated), cells were washed and processed to assess calpain activity. Samples were assayed in quadruplicate (with and without Z-LLY-FMK at $10 \mu \mathrm{M}$, calpain inhibitor). Total calpain activity was determined after subtracting the activity observed in the presence of Z-LLY-FMK; activity was corrected for total protein content, determined by micro-BCA assay (Pierce/thermoscientific). Data are shown as relative calpain activity/ mg protein (mean $\pm \mathrm{SD}$ ).

\section{Scratch assay for assessing cell migration}

CT26 cells were plated in $1 \mathrm{X}$ MEM media containing $10 \%$ FBS, PSQ, NEAA, $100 \% \mathrm{Ca}$ $(1.35 \mathrm{mM})$, and $100 \% \mathrm{Mg}(1.35 \mathrm{mM})$ in $10 \mathrm{~cm}$ dishes. At confluence a scratch was made in the cell monolayer using a sterile $200 \mu$ l pipette tip. Subsequently, the cells were washed twice to remove cell debris and the media was replaced with 1X MEM containing 10\%FBS, PSQ, NEAA, $100 \% \mathrm{Ca}$, and either $100 \% \mathrm{Mg}$ or $10 \% \mathrm{Mg}$, and photographed using a Zeiss Axiovert $200 \mathrm{M}$ Apotome Microscope and then incubated at $5 \% \mathrm{CO}_{2} / 37^{\circ} \mathrm{C}$, for $48 \mathrm{~h}$ and photographed again. The percent wound closure was measured by calculating the area under the scratch at $\mathrm{t}=0$ and at $\mathrm{t}=48 \mathrm{~h}$ using Image $\mathrm{J}$ Software (NIH), as in [25].

\section{Assessment of aneuploidy by flow cytometry}

Following $48 \mathrm{~h}$ exposure of CT26 to the various $\mathrm{Mg}$ - and Ca-culture conditions described above cells were underwent cell cycle analysis of DNA content using flow cytometry based on a method developed by Carbonari et al. [26]. Briefly, cells were lifted with Accutase, and for each condition a total of $0.5 \times 10^{6}$ cells were centrifuged $(300 \mathrm{~g}$, $4 \mathrm{~min}, 20^{\circ} \mathrm{C}$ ) and washed with PBS. Cells were resuspended in PBS containing 10\% FCS (PF10) and absolute formamide (Invitrogen, Carlsbad, CA) was added and gently mixed to obtain a final concentration of 50\% (1:1 v/v) in PF10 (PF10/ FA50). After $10 \mathrm{~min}$ at $20^{\circ} \mathrm{C}$, cells were centrifuged and washed with PF10 and centrifuged again. Cell pellets were resuspended in PF10 containing 7-AAD $(10 \mu \mathrm{g} / \mathrm{ml}$, Sigma Aldrich, USA) and samples were incubated for $60 \mathrm{~min}$ at $20^{\circ} \mathrm{C}$. Cells were washed with $\mathrm{PF} 10$ and resuspended in PF10 and then assessed by flow cytometry (Fortessa Flow Cytometer (BD)) and analyzed using FlowJo software (version 10.1r5; Ashland, OR).

\section{Statistical analyses}

Experiments were performed at least twice and data are expressed as mean $\pm \mathrm{SD}$. One-way ANOVAs were used for multiple comparisons followed by Bonferroni post-hoc testing using GraphPad Prism version 5.04 (GraphPad Soft- 
ware, San Diego, CA, USA). P values $<0.05$ were considered significant.

\section{Results}

\section{Mg status modulates intracellular Ca concentrations and oxidative stress in CT26 tumor cells}

We examined the effect of $\mathrm{MgD}$ exposure on intracellular $\mathrm{Ca}$ concentrations using CT26 colon cancer cells. CT26 cells grown in Mgdeficient conditions $(50 \% \mathrm{Mg}$ or $10 \% \mathrm{Mg}$-containing media with $100 \% \mathrm{Ca}$ ) had significantly higher intracellular $\mathrm{Ca}$ concentrations after $48 \mathrm{~h}$ compared to cells grown with media containing $100 \% \mathrm{Mg}$ (with $100 \% \mathrm{Ca}$ ) (figure 1B). Next, we examined the effect of $\mathrm{Mg}$ supplementation (MgS) after exposure to $\mathrm{MgD}(\mathrm{MgS} / \mathrm{MgD})$ vs. $\mathrm{MgD}$ alone on intracellular $\mathrm{Ca}$ concentrations. The $\mathrm{Ca}$ concentrations in the $\mathrm{MgS} / \mathrm{MgD}$-treated cells were significantly lower than cells grown under continuous $\mathrm{MgD}$ conditions; Ca concentrations in $\mathrm{MgS} / \mathrm{MgD}$ cells were comparable with control cells maintained in $100 \% \mathrm{Mg}$ (figure 1B). When we examined the effect of $\mathrm{MgD}$, when $\mathrm{Ca}$ was decreased proportionally (i.e. Ca: $\mathrm{Mg}$ ratios were 1), on intracellular $\mathrm{Ca}$ concentrations, we found that intracellular Ca levels decreased as the extracellular $\mathrm{Mg}$ and $\mathrm{Ca}$ concentrations declined (figure $1 B$ ). When the $\mathrm{Ca}: \mathrm{Mg}$ ratio was maintained at 1 , CT26 cells grown in $100 \% \mathrm{Mg} /$ $100 \% \mathrm{Ca}$ media had the highest intracellular Ca levels, followed by CT26 cells grown in $50 \% \mathrm{Mg} / 50 \% \mathrm{Ca}$; CT26 cells grown with $10 \% \mathrm{Mg} / 10 \% \mathrm{Ca}$ showed the lowest intracellular $\mathrm{Ca}$ concentrations (figure 1B).

Next, we examined the effect of $\mathrm{Mg}$ status on oxidative stress in CT26 cells using the DCFDA assay. Cells grown in $10 \%$ $\mathrm{Mg} / 100 \% \mathrm{Ca}$ media had significantly higher oxidative stress levels as compared to cells maintained in $100 \% \mathrm{Mg} / 100 \% \mathrm{Ca}$ media, under basal and $\mathrm{H}_{2} \mathrm{O}_{2}$-stimulated conditions (figure 1C). CT26 cells treated with $\mathrm{MgS}$ $(90 \% \mathrm{Mg})$ after $\mathrm{MgD}(10 \% \mathrm{Mg})$ exhibited significantly lower oxidative stress under baseline and $\mathrm{H}_{2} \mathrm{O}_{2}$-stimulated conditions compared with cells maintained in $10 \% \mathrm{Mg}$ (figure $1 \mathrm{C}$ ), supporting that MgS after $\mathrm{MgD}$ reverses the effect of $\mathrm{MgD}$ alone.
TRPM7 expression increases in CT26 cells following $\mathrm{MgD}$ in a $\mathrm{Ca}: \mathrm{Mg}$ ratiodependent manner

Next, we examined the effect of $\mathrm{MgD}$, on the expression of the divalent cation ion channel kinase TRPM7, which is permeable to both $\mathrm{Ca}$ and $\mathrm{Mg}$, and regulates tumor cell invasion and migration [27]. Cells grown in $\mathrm{MgD} /$ $100 \%$ Ca media (with a high Ca: $\mathrm{Mg}$ ratio) for $48 \mathrm{~h}$ showed a dose-dependent increase in TRPM7 expression compared to cells grown in control $100 \% \mathrm{Mg} / 100 \%$ Ca media; this difference was significant with $10 \% \mathrm{Mg} / 100 \% \mathrm{Ca}$ (figure $1 D$ ). When both $\mathrm{Ca}$ and $\mathrm{Mg}$ concentrations were decreased proportionately in the CT26 cell media (maintaining $\mathrm{Ca}: \mathrm{Mg}$ ratio at 1 ), we found no significant change in TRPM7 expression with decreasing $\mathrm{Mg}$ concentrations after $48 \mathrm{~h}$ (figure $1 E$ ).

\section{Calpain 2 expression is not dependent on $\mathrm{Mg}$ or Ca status in CT26 tumor cells}

Next, we examined the effect of $\mathrm{Mg}$ and Ca status on the expression of calpain 2, a Ca-dependent protease that regulates downstream signaling proteins involved in cell motility. CT26 cells exposed to $\mathrm{MgD}$ with $100 \% \mathrm{Ca}$ (with high $\mathrm{Ca}$ : $\mathrm{Mg}$ ratios) for $48 \mathrm{~h}$ showed no difference in calpain 2 expression (figure $1 F$ ). Similarly, when the $\mathrm{Ca}: \mathrm{Mg}$ ratio was kept at 1 there was no change in calpain 2 expression following $\mathrm{MgD}$ (figure 1G).

\section{Calpain activity is enhanced by $\mathrm{Mg}$ deficiency}

Although MgD did not alter calpain 2 expression by CT26 cells, assessment of calpain activity revealed that $50 \% \mathrm{Mg}$ and $10 \% \mathrm{Mg}$ with $100 \% \mathrm{Ca}$ (high Ca:Mg ratios) significantly enhanced calpain activity (vs. $100 \% \mathrm{Mg}$ ) when assessed $24 \mathrm{~h}$ later (figure $1 \mathrm{H}$ ). However, $50 \% \mathrm{Mg}$ appeared to induce more calpain activity than $10 \% \mathrm{Mg}$ conditions (figure $1 \mathrm{H}$ ). This enhancement in calpain activity was not found when CT26 cells were cultured in MgD media with decreasing $\mathrm{Ca}$ concentrations (figure $1 H$ ). When calpain activity was measured at an earlier time point ( $6 \mathrm{~h}$ post $\mathrm{MgD}$ ), $10 \% \mathrm{Mg}$ induced higher calpain activity when compared to $50 \% \mathrm{Mg}$ (with $100 \% \mathrm{Ca}$ ) (figure $1 \mathrm{H}$ ). Next, we 
explored whether MgD promoted calpain activity in other tumor cell lines. We found that $10 \% \mathrm{Mg}$ (with $100 \% \mathrm{Ca}$ ) significantly induced calpain activity in the HCT116 human colon carcinoma cell line $(96,132 \pm 8,188$ $[100 \% \mathrm{Mg} / 100 \% \mathrm{Ca}]$ vs. $143,493 \pm 12764 \quad[10 \%$ $\mathrm{Mg} / 100 \% \mathrm{Ca}$ relative calpain activity/mg protein, $\mathrm{p}<0.001)$, the A2780 human ovarian cancer cell line $(50,428 \pm 7,674[100 \% \mathrm{Mg} / 100 \% \mathrm{Ca}]$ vs. $77,486 \pm 7,957[10 \% \mathrm{Mg} / 100 \% \mathrm{Ca}]$ relative calpain activity/mg protein, $\mathrm{p}<0.005$ ), and the MCF7 human breast cancer cell line $(45,626$ $\pm 3,379[100 \% \mathrm{Mg} / 100 \% \mathrm{Ca}]$ vs. $76,457 \pm 6,511$ $[10 \% \mathrm{Mg} / 100 \% \mathrm{Ca}]$ relative calpain activity/mg protein, $\mathrm{p}<0.0005$ ).

\section{MgD promotes degradation of $\mathrm{N}$-terminal FAK; MgS blocks FAK degradation}

Ca-activated calpain 2 cleaves full-length FAK, important for cell motility, to produce a $90 \mathrm{kDa}$ $\mathrm{N}$-terminal FAK and $35 \mathrm{kDa} \mathrm{C}$-terminal FAK [28]. Here, we examined the effect of $\mathrm{Mg}$ status on the degradation of $\mathrm{N}$-terminal FAK (N-FAK). CT26 cells cultured in $100 \% \mathrm{Mg} / 100 \% \mathrm{Ca}$ media for $48 \mathrm{~h}$ showed $\mathrm{N}$ FAK expression, whereas CT26 cells cultured in $\mathrm{MgD}$ media $(50 \% \mathrm{Mg} / 100 \% \mathrm{Ca}$ and $10 \%$ $\mathrm{Mg} / 100 \% \mathrm{Ca})$ for $48 \mathrm{~h}$ showed no N-FAK expression (figure 2A). Kinetics studies revealed that at $6 \mathrm{~h}, \mathrm{~N}-\mathrm{FAK}$ was expressed by CT26 cells under both $\mathrm{MgD}(10 \% \mathrm{Mg}$ or $50 \% \mathrm{Mg}$ ) and $100 \% \mathrm{Mg}$ (control) conditions (figure $2 B$ ). At $12 \mathrm{~h}$ cells grown with $10 \% \mathrm{Mg}$ expressed less N-FAK protein product when compared to $100 \% \mathrm{Mg}$ (control cells) (figure $2 B$ ). After $18 \mathrm{~h} \mathrm{~N}$-FAK expression in $10 \% \mathrm{Mg}$ exposed cells was significantly decreased (vs. $100 \% \mathrm{Mg}$, control cells), while N-FAK expression in 50\% Mg-exposed cells was decreased to a lesser degree (vs. $100 \% \mathrm{Mg}$, control cells) (figure $2 B$ ). At $24 \mathrm{~h}$, there was no expression of $\mathrm{N}-\mathrm{FAK}$ found in either $10 \% \mathrm{Mg}$ or $50 \% \mathrm{Mg}$ cultured cells (figure 2B) similar to that observed at $48 \mathrm{~h}$ (figure $2 A$ ).

We also investigated whether MgS after $\mathrm{MgD}(\mathrm{MgS} / \mathrm{MgD})$ with $100 \% \mathrm{Ca}$ reversed these effects in CT26 cells. At $24 \mathrm{~h}$ post$\mathrm{MgS} / \mathrm{MgD}$, we observed no N-FAK protein expression; however, at 36h-post $\mathrm{MgS} / \mathrm{MgD}$, the N-FAK protein product was observed and its expression was further increased at $48 \mathrm{~h}$ (figure $2 A$ ).

\section{MgD leads to p53 degradation in CT26 cells and this is rescued by MgS}

Calpain also degrades p53 [29]. Therefore, we examined p53 expression by CT26 cells cultured under various $\mathrm{Mg}$ concentrations. Similar to NFAK at $48 \mathrm{~h}, \mathrm{p} 53$ expression was not observed (presumably degraded) under $\mathrm{MgD}$ conditions (10\% $\mathrm{Mg}$ and $50 \% \mathrm{Mg}$ with $100 \% \mathrm{Ca}$ ), whereas it was expressed when cells were in $100 \% \mathrm{Mg} /$ $100 \%$ Ca media (figure 2A). The kinetics study showed that p53 was expressed by cells maintained for $6 \mathrm{~h}$ in both $\mathrm{MgD}$ (containing $10 \%$ or $50 \% \mathrm{Mg}$ ) and control media (containing $100 \% \mathrm{Mg}$ ) with $100 \% \mathrm{Ca}$ (figure $2 B$ ). Loss of p53 expression was first detected $12 \mathrm{~h}$ post$10 \% \mathrm{Mg}$ (figure $2 \mathrm{~B}$ ) and it was almost undetectable by $18 \mathrm{~h}$ post- $10 \% \mathrm{Mg}$, while CT26 cells maintained in $50 \% \mathrm{Mg}$ showed reduced p53 expression when compared to $100 \% \mathrm{Mg}$ (control)-exposed cells (figure 2B). At $24 \mathrm{~h}$, no p53 expression was detected in cells exposed to either $10 \% \mathrm{Mg}$ or $50 \% \mathrm{Mg}$, whereas cells grown in $100 \% \mathrm{Mg}$-media retained p53 expression (figure 2B). Also, we examined the effect of MgS/MgD on p53 expression; p53 expression was not restored after $24 \mathrm{~h}$ post-MgS/MgD but it was detected $36 \mathrm{~h}$ post-MgS/MgD and expression increased at $48 \mathrm{~h}$ post- $\mathrm{MgS} / \mathrm{MgD}$ compared to $\mathrm{MgD}$ alone (figure $2 \mathrm{~A}$ ).

\section{MgD regulates key NF- $\kappa$ B pathway proteins in CT26 cells}

The NF- $\kappa$ B pathway is implicated in tumorigenesis and tumor progression, as cancer cells exhibit constitutive NF- $\mathrm{kB}$ activation. Next, we examined the effect of $\mathrm{Mg}$ status on the canonical $\mathrm{NF}-\kappa \mathrm{B}$ pathway proteins, IкB $\alpha$ and p65 (RelA). Full-length $\mathrm{I} \kappa \mathrm{B} \alpha$ protein $(39 \mathrm{kDa})$ that inhibits $\mathrm{NF}-\kappa \mathrm{B}$ activation can be cleaved by calpain. At $48 \mathrm{~h}$ post-MgD $(50 \% \mathrm{Mg}$ and $10 \% \mathrm{Mg} / 100 \% \mathrm{Ca})$ CT26 cells expressed an I $\mathrm{B} \mathrm{B} \alpha$ cleavage product when compared to $100 \% \mathrm{Mg} / 100 \%$ Ca-exposed cells, which only expressed the full-length protein (figure 2A). The time course experiment shows that the expression of full-length $I \kappa B \alpha$ began to decrease in $10 \% \mathrm{Mg}$-exposed cells after $12 \mathrm{~h}$ (figure $2 \mathrm{~B}$ ). By $18 \mathrm{~h}$-post $\mathrm{MgD}$, the fulllength $\mathrm{I} \kappa \mathrm{B} \alpha$ protein completely disappeared with $10 \% \mathrm{Mg}$, whereas two bands (one corresponding to the full-length $\operatorname{I\kappa B} \alpha(39 \mathrm{kDa}))$ and a lower band consistent with the 30-40 amino acid 


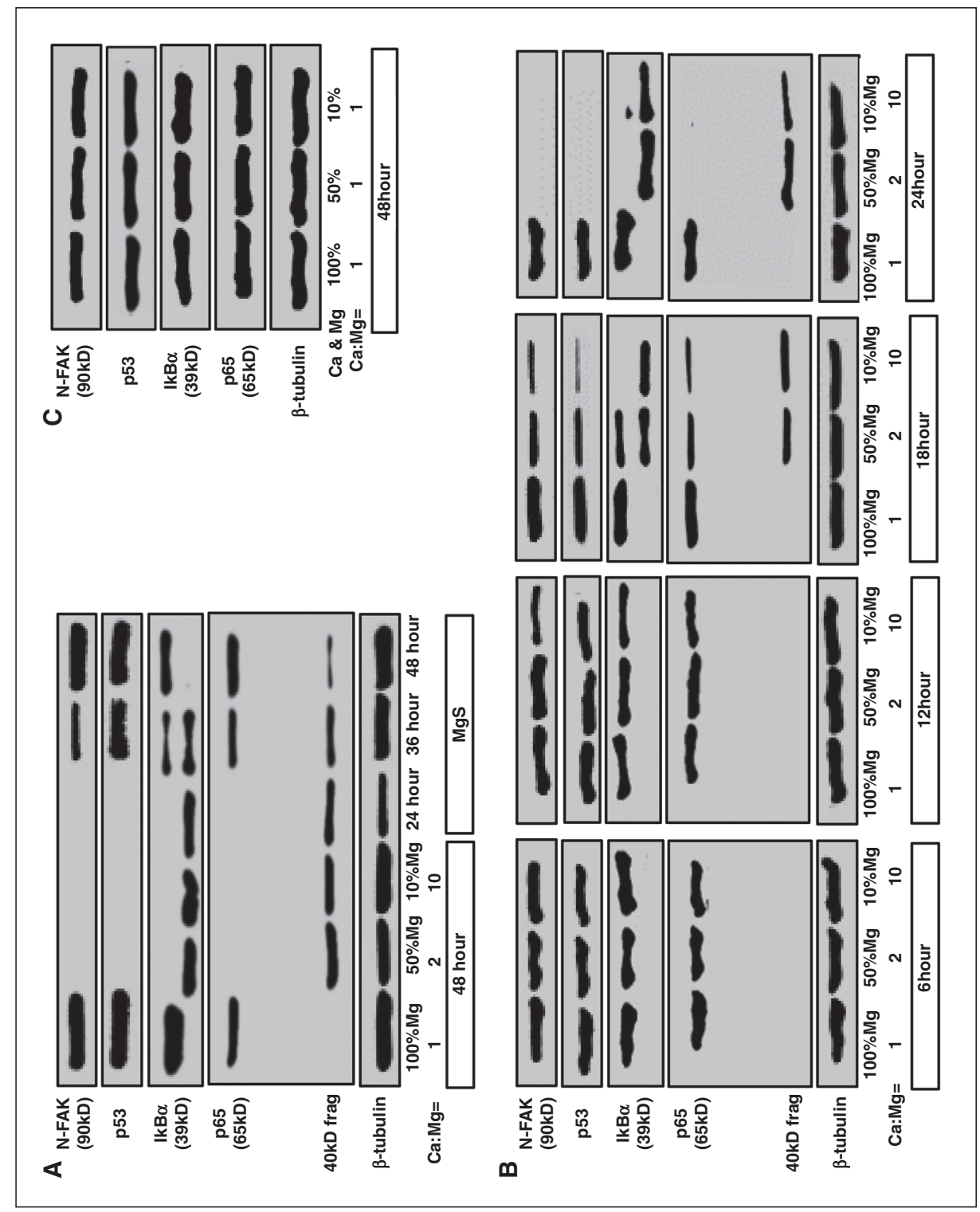

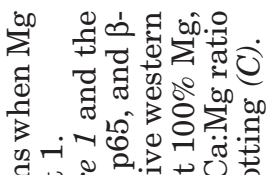

पी -

5 ,

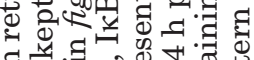

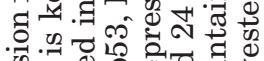

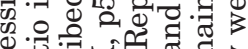

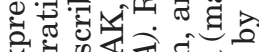
Q

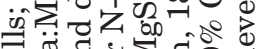

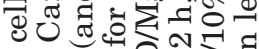
œ U :

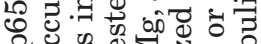
2.

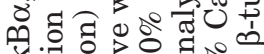
चn 은 \%

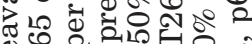
要

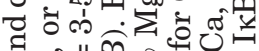
สี ชิ

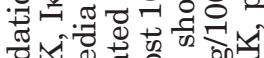
उ

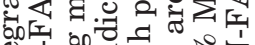

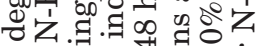
คొ

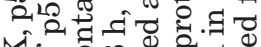

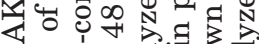

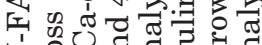

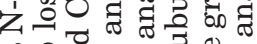

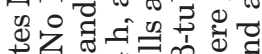
पै

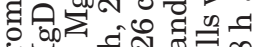

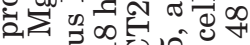
คิ

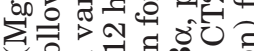

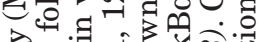
创 क्ष 0 n

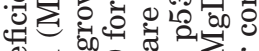

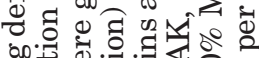

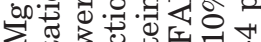

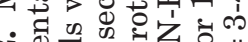
ง

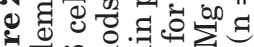

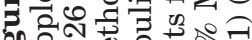

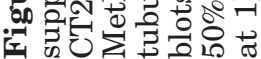


cleaved product were observed in cells grown under $50 \% \mathrm{Mg}$ at $18 \mathrm{~h}$ (figure $2 B$ ). After $24 \mathrm{~h}$, $100 \% \mathrm{Mg}$-exposed cells continued to express full-

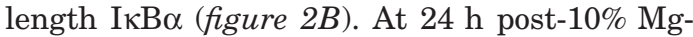
and $50 \% \mathrm{Mg}$-exposure CT26 cells expressed a single I $\mathrm{B} \alpha$ band corresponding to the cleaved product (figure $2 B$ ). After $24 \mathrm{~h}$ of $\mathrm{MgS} / \mathrm{MgD}$ only the cleaved I $\mathrm{B} \alpha \alpha$ product was found and at $36 \mathrm{~h}$ both full-length $\mathrm{I} \kappa \mathrm{B} \alpha$ and some cleaved product was found (figure $2 A$ ). By $48 \mathrm{~h}$ post-MgS/MgD full-length $\mathrm{I} \kappa \mathrm{B} \alpha$ was prominently expressed (figure 2A).

The full-length p65 subunit of $\mathrm{NF}-\kappa \mathrm{B}$ is $65 \mathrm{kDa}$ and its cleaved $40 \mathrm{kDa}$ product lacks the C-terminal transactivation domain required for the transcription of target genes [30]. We examined p65 protein expression (and its cleavage product) by CT2 6 cells under $\mathrm{MgD} /$ $100 \% \mathrm{Ca}$ conditions. At $48 \mathrm{~h}$ a single $65 \mathrm{kDa}$ $\mathrm{NF}-\kappa \mathrm{B}$ band was expressed by cells grown in $100 \% \mathrm{Mg} / 100 \% \mathrm{Ca}$, whereas cells maintained in $\mathrm{MgD}$ media $(50 \%$ and $10 \% \mathrm{Mg}) / 100 \% \mathrm{Ca}$ expressed a single $40 \mathrm{kDa} \mathrm{NF}-\mathrm{\kappa B}$ cleavage product (lacking the $\mathrm{C}$-terminal transactivation domain) (figure 2A). Our kinetics study showed that at $6 \mathrm{~h}$ post-MgD, there was no cleavage of $\mathrm{p} 65$, at $12 \mathrm{~h}$-post $\mathrm{MgD}$ less full-length $\mathrm{p} 65$ protein was observed in CT26 cells cultured in $10 \% \mathrm{MgD}$ media (vs. $100 \% \mathrm{Mg}$ media) and by $18 \mathrm{~h}$-post $\mathrm{MgD}$ the amount of full-length p65 was dramatically reduced in the $50 \% \mathrm{Mg}$ exposed cells (vs. 100\% Mg-exposed cells); this was accompanied by an increase in the $40 \mathrm{kDa}$ cleavage product (figure $2 B$ ). CT26 cells maintained in $50 \% \mathrm{Mg}$-containing media for $18 \mathrm{~h}$ showed some expression of the full-length p65 protein, but this was weaker than $100 \% \mathrm{Mg}$-exposed cells and stronger than the expression levels observed with $10 \% \mathrm{Mg}$ (figure $2 B$ ). In addition, the cleaved $40 \mathrm{kDa}$ $\mathrm{NF}-\kappa \mathrm{B}$ band was weaker in intensity when compared to cells grown with $10 \% \mathrm{Mg}$ (figure $2 B$ ). At $24 \mathrm{~h}$ under $\mathrm{MgD}$ conditions $(10 \% \mathrm{Mg}$ and $50 \% \mathrm{Mg}$ ) only a single $40 \mathrm{kDa} \mathrm{NF}$ $\mathrm{\kappa B}$ product was found (figure $2 B$ ). Similarly, at $24 \mathrm{hr}$ post-MgS/MgD only the $40 \mathrm{kDa}$ cleavage product was observed (figure $2 A$ ); at $36 \mathrm{~h}$ post$\mathrm{MgS} / \mathrm{MgD}$ the full-length $\mathrm{p} 65$ protein was found with some $40 \mathrm{kDa}$ cleavage product, whereas at $48 \mathrm{~h}$ post-MgS/MgD the full-length p65 band was prominently expressed with faint expression of the $40 \mathrm{kDa}$ cleavage product (figure 2A).

\section{No loss of N-FAK, p53, I $\kappa \mathrm{B} \alpha$, or p65 when CT26 cells are cultured in MgD media when Ca:Mg ratios are maintained at 1}

As we determined that TRPM7 expression by CT26 cells was not dependent on $\mathrm{MgD}$ but rather on the $\mathrm{Ca}: \mathrm{Mg}$ ratio in media, we examined the expression of $\mathrm{p} 53, \mathrm{~N}-\mathrm{FAK}, \mathrm{I} \kappa \mathrm{B} \alpha$, and $\mathrm{p} 65$ when $\mathrm{Ca}$ was decreased in proportion to $\mathrm{Mg}$ in the media. When the Ca:Mg ratio was kept at 1 , no loss of p53, N-FAK, full-length $\mathrm{I} \kappa \mathrm{B} \alpha$, or p 65 was observed when CT26 cells were cultured in $10 \% \mathrm{Mg} / 10 \% \mathrm{Ca}$ or $50 \% \mathrm{Mg} / 50 \% \mathrm{Ca}(\mathrm{MgD}) \mathrm{me}-$ dia (figure $2 \mathrm{C}$ ).

\section{MgD leads to loss of full-length E- cadherin and $\beta$-catenin; no loss when Ca: $\mathrm{Mg}$ ratio is 1}

Full-length E-cadherin $(120 \mathrm{kDa})$ is a glycoprotein important for cell-cell adhesion. When we examined the effect of $\mathrm{MgD}$ on E-cadherin expression in CT26 cells after $48 \mathrm{~h}$, we found that cells grown in $10 \% \mathrm{Mg} / 100 \% \mathrm{Ca}$ and $50 \% \mathrm{Mg} / 100 \%$ Ca-media lacked expression of the full length E-cadherin protein, but showed increased expression of the cleaved $100 \mathrm{kDa}$ E-cadherin fragment (figure $3 A$ ). In contrast, $100 \% \mathrm{Mg} / 100 \%$ Ca-exposed CT26 cells expressed the full-length E-cadherin, as well as the cleaved $100 \mathrm{kDa}$ fragment (less when compared to $\mathrm{MgD}$ ). This fragment, generated via calcium-calpain-dependent pathway, is unable to bind $\beta$-catenin and promotes metastasis [17]. Our kinetic studies revealed that at $6 \mathrm{~h}$ post $\mathrm{MgD}$, the expression of full-length E-cadherin was observed under all $\mathrm{Mg}$ conditions, but CT26 cells cultured in $10 \% \mathrm{Mg} / 100 \% \mathrm{Ca}$ media showed increased levels of the cleaved $100 \mathrm{kDa}$ fragment when compared to cells cultured in $50 \% \mathrm{Mg} / 100 \%$ Ca-media or $100 \% \mathrm{Mg} / 100 \% \mathrm{Ca}-$ media (figure $3 \mathrm{~A}$ ). At $12 \mathrm{~h}$ post $\mathrm{MgD}$ there was loss of full-length E-cadherin in the $10 \% \mathrm{Mg} /$ $100 \% \mathrm{Ca}$-exposed cells, and at $24 \mathrm{~h}$ post $\mathrm{MgD}$ the level of E-cadherin was similar to that found at $48 \mathrm{~h}$ (figure $3 \mathrm{~A}$ ). In addition, we examined the effect of $\mathrm{Mg}$ status on $\beta$-catenin expression in CT26 cells at $48 \mathrm{~h}$ and found that full-length $\beta$ catenin $(92 \mathrm{kDa})$ expression was only present in the 100\% Mg-exposed CT26 cells, whereas the $\mathrm{MgD}$-exposed CT26 cells expressed a $75 \mathrm{kDa} \beta$ catenin cleavage product (figure S1A). When CT26 cells were maintained in media where the 

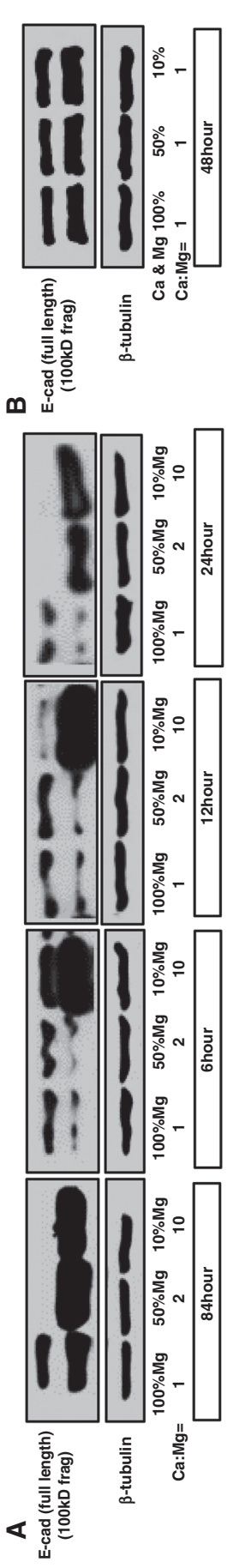

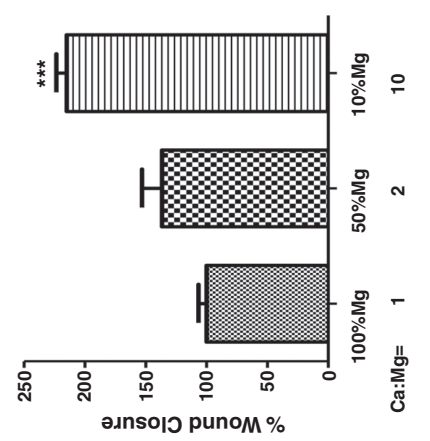

口

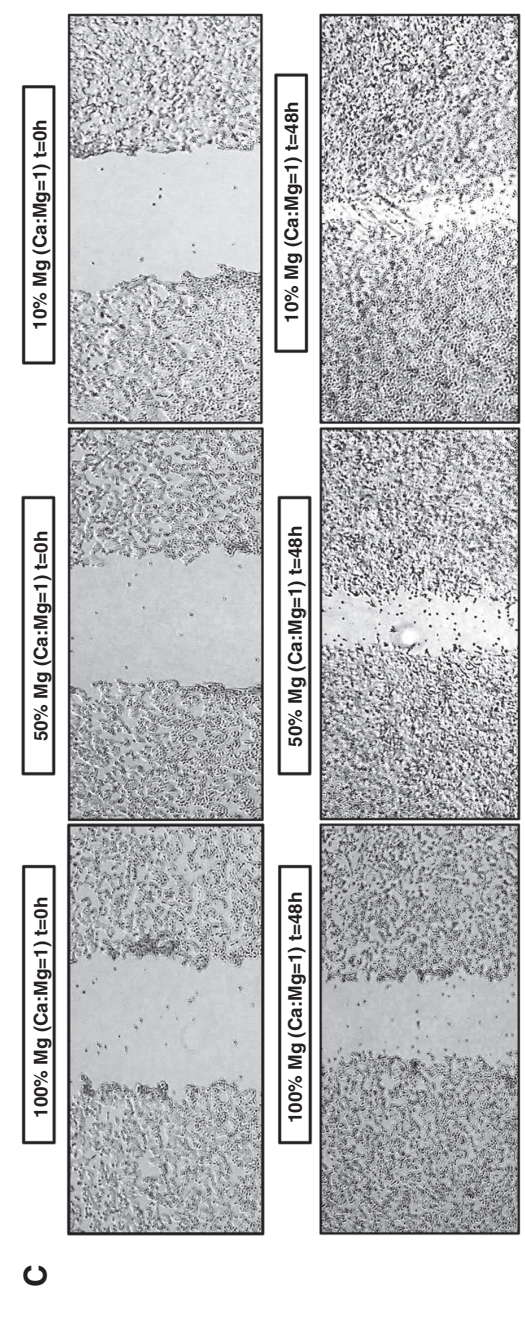

\&

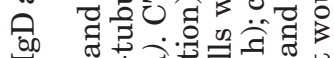

之.

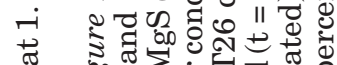

苨

政

.2

.

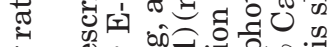

क ठ ठ

宓

उ 지응어

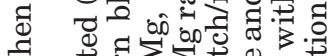

उ

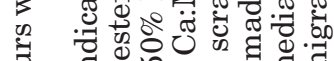

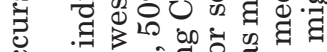

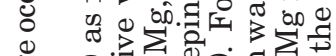

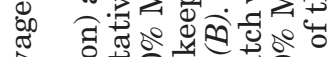

ส

记

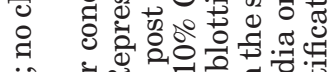

in के क्ष

ఖ

का

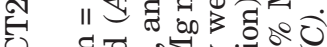

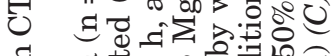

厅

.

बै

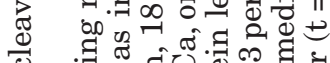

ए च च

.

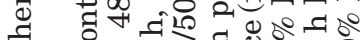

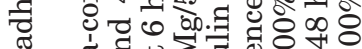

ฮ ฮี

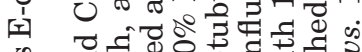

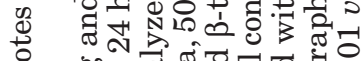

๕

० $\quad \sum_{0}^{\infty}$ ส

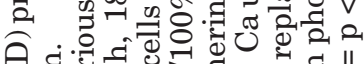

के द्व

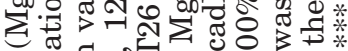

하워

. ప્व

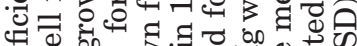

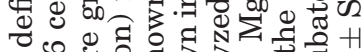
200 유

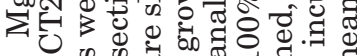
कि थी जी की

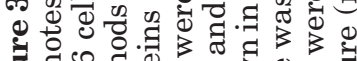

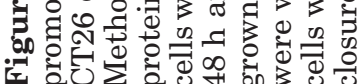


Ca: $\mathrm{Mg}$ ratio was kept at 1 , no loss of E-cadherin (figure $3 B$ ) or $\beta$-catenin (figure $S 1 B$ ) was observed with any MgD conditions.

\section{MgD (with a high Ca:Mg ratio) increases the migration of CT26 colon cancer cells}

Based on our previous results showing that CT26 cells cultured under $\mathrm{MgD} / 100 \%$ Ca conditions (with high Ca:Mg ratios) expressed stressrelated signaling pathways associated with motility/migration, we examined the effect of $\mathrm{MgD}$ on the migration of CT26 cells using the scratch assay. While cells maintained in $50 \% \mathrm{Mg} / 100 \% \mathrm{Ca}$-media for $48 \mathrm{~h}$ showed slightly increased migration when compared to cells maintained in $100 \% \mathrm{Mg} / 100 \% \mathrm{Ca}$-media for $48 \mathrm{~h}$, cells maintained in $10 \% \mathrm{Mg} / 100 \% \mathrm{Ca}$ media exhibited significantly enhanced migration when compared to cells maintained in $100 \% \mathrm{Mg} / 100 \%$ Ca-media (figure 3C-D).

\section{CT26 cells maintained in MgD media (with a high Ca:Mg ratio) exhibit increased aneuploidy; MgD media is not associated with increased aneuploidy when Ca:Mg ratio is 1}

We showed that $\mathrm{MgD}$ increases oxidative stress in CT26 cells and the loss of p53, the guardian of the genome. Therefore, we investigated the effect of $\mathrm{MgD}$ with varying $\mathrm{Ca}: \mathrm{Mg}$ ratios on baseline aneuploidy, a phenotype that can lead to genomic instability. Baseline aneuploidy of CT26 cells grown in $100 \% \mathrm{Mg} / 100 \% \mathrm{Ca}$ was denoted as $100 \%$. When cells were cultured in $50 \% \mathrm{Mg} / 100 \%$ Ca-containing media aneuploidy increased to $134 \%$ and this was dramatically increased to $178 \%$ when the cells were cultured in $10 \% \mathrm{Mg} / 100 \% \mathrm{Ca}$ (figure $4 A-D$ ). When the Ca: $\mathrm{Mg}$ ratios were maintained at 1, CT26 colon cancer cells exhibited $100 \%$ aneuploidy when maintained in $100 \% \mathrm{Mg} / 100 \%$ Ca-media, and $97 \%$ and $100.5 \%$ aneuploidy when maintained in $50 \% \mathrm{Mg} / 50 \%$ Ca-media and $10 \% \mathrm{Mg} / 10 \% \mathrm{Ca}-$ media, respectively (figure $4 E-H$ ).

\section{Discussion}

Inadequate $\mathrm{Mg}$ consumption is widespread, while Ca supplementation is prevalent [31]. Consistent with this imbalance, several epide- miological studies have linked higher dietary Ca: $\mathrm{Mg}$ ratios with increased incidences of cancers, including colon cancer [15, 17-19, 32,33] and higher rates of cancer mortality $[15,16]$. In this study we showed that culturing murine CT26 colon cancer cells in media containing insufficient $\mathrm{Mg}$ concentrations with a constant, normal (100\%) Ca concentration (increased Ca:Mg ratios) dramatically affects calpain activity, oxidative stress, cell migration, and aneuploidy, as well as the expression of several components of signaling pathways leading to a metastaticlike phenotype. By contrast, decreasing Ca levels in proportion with decreasing $\mathrm{Mg}$ levels (keeping the Ca: $\mathrm{Mg}$ ratio at 1 ) had little or no effect on calpain activity, oxidative stress, cell migration, aneuploidy, or the expression of several components of associated signaling pathways.

$\mathrm{Mg}$ serves as nature's physiological Ca channel antagonist [6] (figure 1A). Using the CT26 colon cancer cell line we demonstrated that $\mathrm{MgD}$ (10\% Mg, $50 \% \mathrm{Mg}$ ) when accompanied by higher $\mathrm{Ca}: \mathrm{Mg}$ ratios increased intracellular calcium concentrations (figure 1B). In addition, MgS post-MgD (10\% Mg, followed by $90 \% \mathrm{Mg}$ [100\% Mg final]) decreased intracellular $\mathrm{Ca}$ concentrations comparable to control cells maintained in $100 \% \mathrm{Mg}$ (figure $1 B$ ). This likely occurs by preventing Ca entry and/or by controlling the efflux of $\mathrm{Ca}$ out of the cells possibly by regulating Ca-ATPase pumps in the plasma membrane and $\mathrm{SER}$, as Mg is a cofactor for the activity of ATP. Due to the gating property of $\mathrm{Mg}$ on intracellular $\mathrm{Ca}$ entry when Ca:Mg ratios were maintained at 1, intracellular $\mathrm{Ca}$ concentrations decreased as the extracellular $\mathrm{Ca}$ (and $\mathrm{Mg}$ ) concentrations in the media decreased (figure 1B).

The relationship between $\mathrm{MgD}$ and oxidative stress is well documented [34]. Mg deficiency has been implicated in the initiation and progression of cancer by promoting oxidative stress and inflammation [10]. MgD promotes oxidative stress by decreasing the antioxidant defense of cells and by increasing intracellular $\mathrm{Ca}$ concentrations leading to intracellular $\mathrm{Ca}$ overload. Using the DCFH-DA assay, we observed that $\mathrm{MgD}$ with $100 \% \mathrm{Ca}$ increased oxidative stress in CT26 cells under baseline and $\mathrm{H}_{2} \mathrm{O}_{2}$-stimulated conditions and this effect was reversed by $\mathrm{Mg}$ supplementation following $\mathrm{Mg}$ deficiency (figure 1C). Oxidative stress can activate TRPM7, which plays an important role in regulating intracellular $\mathrm{Mg}, \mathrm{Ca}$, and $\mathrm{Zn}$ homeo- 

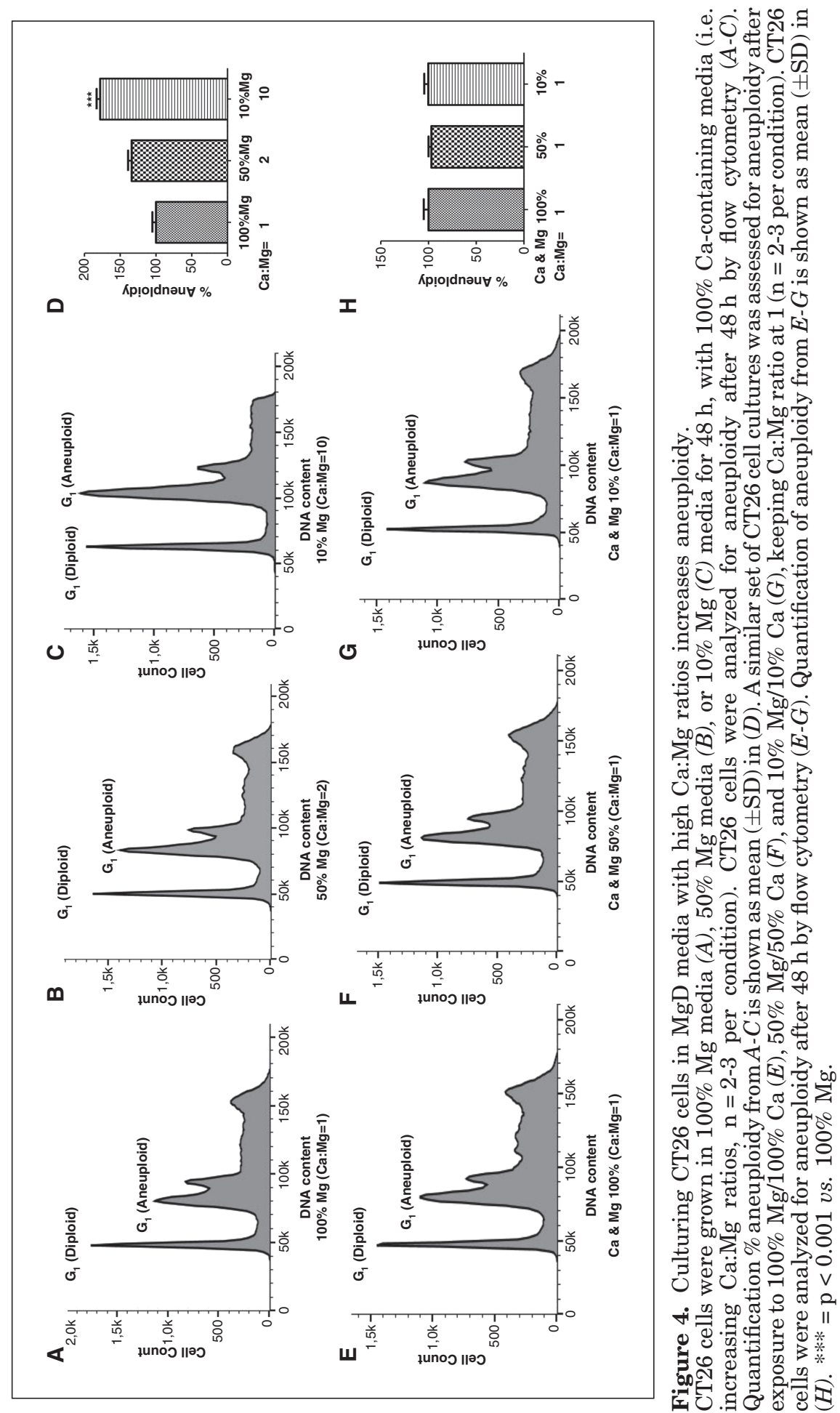


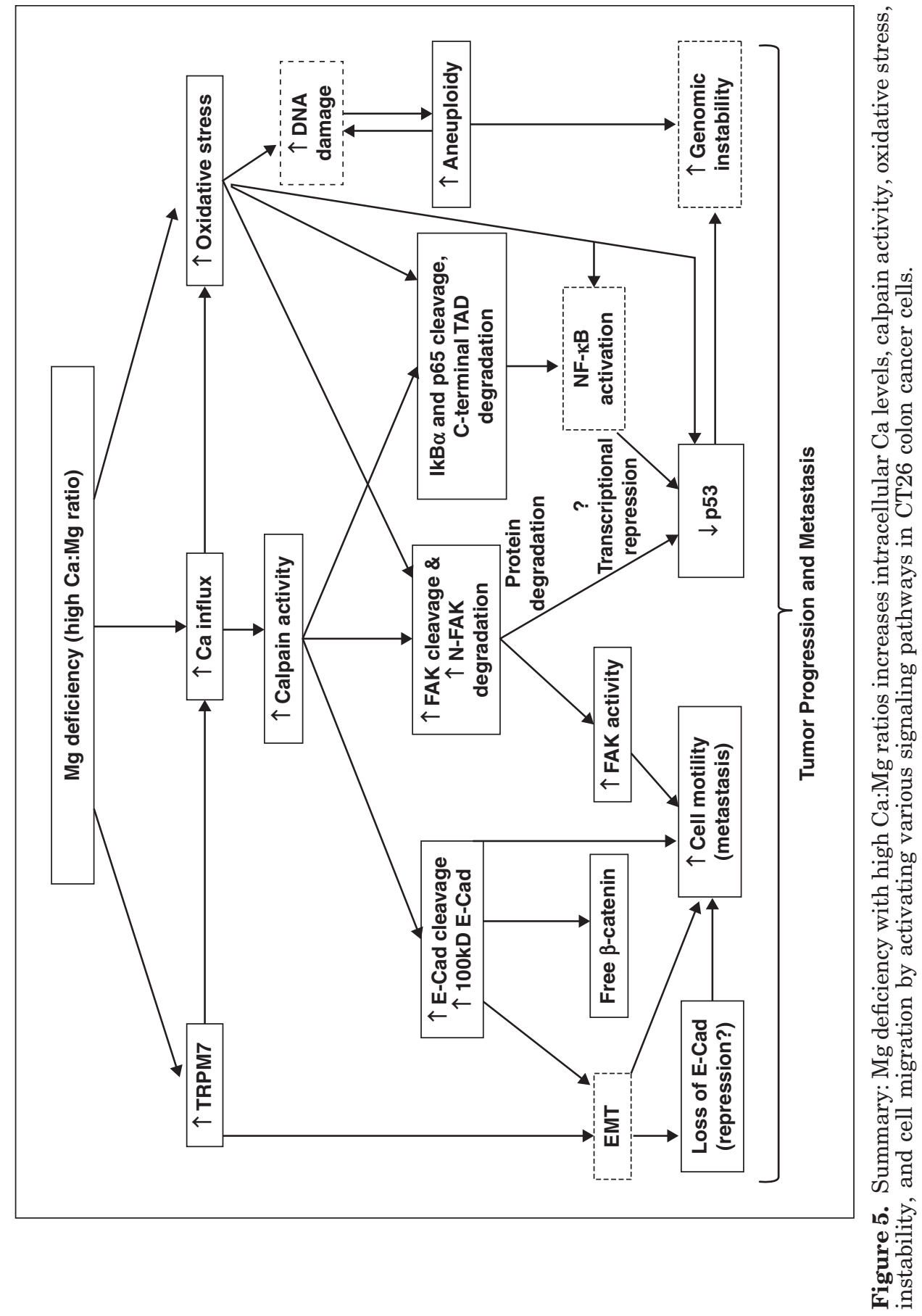


stasis. This channel pore preferentially permits the flow of $\mathrm{Mg}$ and to a lesser extent $\mathrm{Ca}$ [35-38]. Cancer cells exhibit increased TRPM7 expression [39], which has been shown to promote cell migration and epithelial to mesenchymal transition (EMT). In CT26 colon cancer cells, TRPM7 expression was dependent on the $\mathrm{Ca}: \mathrm{Mg}$ ratio in the media, with enhanced TRPM7 expression under $\mathrm{MgD}$ conditions with higher $\mathrm{Ca}: \mathrm{Mg}$ ratios (figure 1D), whereas no change in TRPM7 expression was found when the $\mathrm{Ca}: \mathrm{Mg}$ ratio was kept at 1 (figure 1E). Our findings are consistent with Sun et al. who reported similar results (higher TRPM7 with higher $\mathrm{Ca}: \mathrm{Mg}$ ratios) using human prostate cancer specimens [17] and Santos and Hussain, who showed that exogenously added $\mathrm{Mg}$ significantly reduced prostate cancer cell migration [40]. However, they are not consistent with Baldoli et al., who reported that $\mathrm{Mg}$ deficiency $(0.1 \mathrm{mM})$ reduced TRPM7 protein expression and decreased human microvascular endothelial cell migration [41]. The exact reasons for these differences are not known. It is possible that primary endothelial cells vs. cancer cell lines exhibit different gene expression profiles and motility differences. The CT26 cell line harbors a Kras mutation, expresses several cancer-relevant genes (e.g. Nras, Vegfa, and $M y c$ ), and has lost tumor suppressor gene expression (e.g. Cdkn2a) $[42,43]$. This gene expression profile is very different from primary endothelial cells and may impact cell motility. In addition, cancer cells may be able to better tolerate high stress environments and utilize increased intracellular $\mathrm{Ca}$ to promote pathways that enhance their motility. For example, intracellular Ca in cancer cells may modulate classical receptor kinase signaling pathways leading to changes in cell matrix adhesion and myosin contraction that promote migration (as described by [44]). Future studies are needed to explore the cell specificity of our findings.

Because epidemiological studies support that $\mathrm{MgD}$ and increased $\mathrm{Ca}: \mathrm{Mg}$ intake ratios enhance mortality among patients with colorectal cancer [15], we studied the effect of $\mathrm{MgD}$ on cell migration and signaling pathways/markers associated with aggressive, metastatic-like phenotypes using CT26 colon cancer cells. Culturing CT26 cells in $10-50 \% \mathrm{MgD} / 100 \% \mathrm{Ca}$ media increased cell migration when compared to cells maintained in $100 \% \mathrm{Mg} / 100 \% \mathrm{Ca}$ media (figure $3 C-3 D$ ). These findings are consistent with studies by Nasulewicz et al. showing increased metastases in mice following an $\mathrm{MgD}$ diet (with high Ca:Mg ratio) [45]. Increased intracellular $\mathrm{Ca}$ is implicated in cell motility, an important aspect of tumor invasion and metastasis [46], and therefore, we examined the effect of $\mathrm{Mg}$ and $\mathrm{Ca}$ status on the expression of calpain 2, a Ca-dependent cysteine protease that catalyzes limited proteolysis of several proteins involved in cell motility. Increased calpain expression has been reported in numerous types of cancer, including colorectal carcinomas [4749]. We found that in CT26 cells, calpain 2 protein expression was independent of extracellular $\mathrm{Ca}$ or $\mathrm{Mg}$ status (figure $1 F-1 G$ ), suggesting that calpain activity is modified by increasing intracellular $\mathrm{Ca}$ concentrations. Using a fluorescence-based calpain activity assay, we found that $50 \% \mathrm{Mg}$ and $10 \% \mathrm{Mg}$ (with $100 \% \mathrm{Ca}$, high $\mathrm{Ca}: \mathrm{Mg}$ ratios) significantly induced calpain activity in the CT26 cell line (figure $1 H$ ); the earlier (6hr) time point showed a dose-response curve, suggesting that compensatory pathways and Ca utilization may occur by the $24 \mathrm{hr}$ time point. By contrast, calpain activity was not altered when both $\mathrm{Mg}$ and $\mathrm{Ca}$ concentrations were reduced equally, to maintain $\mathrm{Ca}: \mathrm{Mg}$ at 1 (figure $1 \mathrm{H}$ ). Furthermore, we observed that $10 \% \mathrm{MgD} / 100 \% \mathrm{Ca}$ treatment of other cancer cell lines (A2780 human ovarian cancer, MCF7 human breast cancer, and HCT116 human colon cancer) also significantly promoted calpain activity levels over $100 \% \mathrm{Mg} / 100 \%$ Ca-treated cells; these findings show that our results are not restricted to CT26 mouse colon cancer cells.

Next, using CT26 cells we examined the effects of $\mathrm{MgD}$ on downstream targets of calpain. Since calpain proteolyzes both FAK [28] and p53 [29] and we demonstrated that $\mathrm{MgD} / 100 \% \mathrm{Ca}$ increases intracellular $\mathrm{Ca}$ and oxidative stress, we examined the effect of $\mathrm{MgD} / 100 \% \mathrm{Ca}$ on $\mathrm{N}$ FAK and p53 degradation. MgD/100\% Ca-exposed CT26 colon cancer cells exhibited reduced expression of N-FAK in a time-dependent manner (figure 2A-B). By $24 \mathrm{hr}$ post-MgD/ $100 \% \mathrm{Ca}$ the degradation of N-FAK was complete. We also observed the time-dependent reappearance of N-FAK when the cells were treated with $\mathrm{MgS} / \mathrm{MgD}$ (figure $2 A$ ). FAK plays an important role in various cancer processes, such as migration and invasion [50-52]. Although not demonstrated, we propose that $\mathrm{MgD}$ leads to the 
formation of a truncated FAK, lacking the Nterminal FERM domain, which displays higher catalytic activity, as described by Jacamo [53]. Similarly, we found that $\mathrm{MgD} / 100 \% \mathrm{Ca}$-exposure of CT26 cells reduced p53 expression in a time-dependent manner, with complete loss by $24 \mathrm{hr}$. Consistent with our finding with FAK, we also observed the time-dependent reappearance of p53 following MgS for 36-48 h (after $\mathrm{MgD}$, figure $2 \mathrm{~A}$ ). Studies by Lim et al. showing that FAK enters the nucleus, where its Nterminus binds p53 and degrades it, while FAK binds Mdm2 (an E3 ubiquitin ligase that negatively regulates p53) leading to the ubiquitination and degradation of the FAK complex [54] provide a potential mechanism for the loss of p53 and FAK expression by MgDexposed CT26 cells.

$\mathrm{NF}-\kappa \mathrm{B}$ can be activated by reactive oxygen species (ROS), DNA damage, and oncogenic stress from inside the cells [55]. In vitro studies have demonstrated that both $\mathrm{I} \kappa \mathrm{B} \alpha$ and $\mathrm{NF}-\kappa \mathrm{B}$ p65 are substrates of calpain [56, 57]. Here, $\mathrm{MgD} / 100 \%$ Ca-exposed CT26 cells showed cleavage of full-length $\mathrm{I} \kappa \mathrm{B} \alpha$ to a smaller fragment, corresponding to the loss of approximately 30-40 amino acids, in a time-dependent manner and cleavage was complete by $24 \mathrm{hr}$ (figure $2 A-B$ ). $\mathrm{MgS}$ post-MgD resulted in the re-expression of full-length I $\mathrm{B} \mathrm{\alpha} \alpha$ and loss of the cleaved fragment by $36 \mathrm{hr}$ post $\mathrm{MgS}$ (figure $2 \mathrm{~A}$ ). I $\mathrm{BB} \alpha$ cleavage allows nuclear translocation of the p65 subunit of NF-кB. We found that MgD-exposed CT26 cells expressed a cleaved fragment of p65 corresponding to the $40 \mathrm{kDa}$ fragment lacking the transactivation domain (required for gene transcription) (figure $2 A-B$ ). MgS post-MgD/ $100 \% \mathrm{Ca}$ led to expression of full-length p65 at $36 \mathrm{~h}$, which was further enhanced $48 \mathrm{~h}$-post $\mathrm{MgS}$ (figure 2A).

E-cadherin expression or its cell surface localization is often lost in aggressive or advanced tumors and this loss is associated with increased metastasis and tumor recurrence $[58,59]$. The loss of E-cadherin expression is associated with metastasis and worse prognosis in colon cancer; this is more often due to posttranslational modifications rather than genetic mutation [60]. Rios-Doria and Day et al. reported that cleavage of full-length E-cadherin to its $100 \mathrm{kDa}$-fragment occurs in a calcium-calpaindependent manner [61]; this E-cadherin fragment is unable to bind to $\beta$-catenin, $\gamma$-catenin, or p120, which are essential for the cell adhesion and signaling functions of E-cadherin [61, 62]. In one study, all metastatic prostate tumors expressed the $100 \mathrm{kDa}$ E-cadherin fragment, whereas localized prostate tumors did not express it [61]. Accordingly, we found that MgD-exposed CT26 cells (with increasing Ca: $\mathrm{Mg}$ ratios) showed loss of full-length E-cadherin in a time-dependent manner, accompanied by increasing levels of the $100 \mathrm{kDa}$ cleaved product (figure 3A). As cleaved E-cadherin is unable to bind $\beta$-catenin, we also examined the effect of $\mathrm{MgD}$ on $\beta$-catenin expression and found that MgD-exposed CT26 cells did not express fulllength $\beta$-catenin, but expressed a $75 \mathrm{kDa}$ cleaved product, with highest expression following $10 \% \mathrm{Mg}$ (figure S1A).

Our results support that $\mathrm{Mg}$ status regulates intracellular $\mathrm{Ca}$ concentrations and oxidative stress leading to altered signaling pathways via calpain-mediated cleavage of target proteins and/or oxidative stress-induced changes that are associated with more aggressive tumors. Our next objective was to assess similar pathways and proteins after maintaining CT26 cells in $\mathrm{MgD}$-media where $\mathrm{Ca}: \mathrm{Mg}$ ratios were kept at 1. Exposure of CT26 cells to decreasing concentrations of $\mathrm{Mg}$ and $\mathrm{Ca}$ (with a constant $\mathrm{Ca}: \mathrm{Mg}$ ratio of 1) maintained the levels of p53, N-FAK, $\mathrm{I \kappa} \mathrm{B} \alpha$, p65 (figure 2C), full-length E-cadherin (figure $3 B$ ), and $\beta$-catenin (figure $S 1 B$ ). We propose that $\mathrm{MgD}$ relative to $\mathrm{Ca}$ in the extracellular media may promote $\mathrm{Ca}$ influx, with release of $\mathrm{Ca}$ from intracellular stores followed by activation of the store operated calcium entry mechanism contributing to sustained intracellular $\mathrm{Ca}$ concentrations. MgS following $\mathrm{MgD}$ exposure likely promotes the extrusion of cytosolic Ca levels in CT26 cells possibly by activating the ATP-dependent $\mathrm{Ca}$ pumps.

We observed enhanced oxidative stress and loss of p53 in MgD-exposed CT26 cells (figure 1C and figure $2 A-B$ ). Since oxidative stress leads to DNA damage and p53 stimulates various DNA repair mechanisms [63] and serves as the guardian of the genome by triggering growth arrest following DNA damage [64], we examined the effect of MgD exposure of CT26 cells on aneuploidy, a marker of genomic instability. $\mathrm{MgD}$ with $100 \% \mathrm{Ca}$ (high Ca:Mg ratios) significantly enhanced aneuploidy in $\mathrm{G}_{1}$ cells (figure $4 A-D$ ). By contrast, CT26 cells main- 
tained in media with a $\mathrm{Ca}: \mathrm{Mg}$ ratio at 1 , showed no change in baseline aneuploidy with decreasing $\mathrm{Mg}$ and Ca levels (figure $4 \mathrm{E}-\mathrm{H}$ ). An alternate explanation for this finding is that the aneuploid cell population is proliferating more rapidly under conditions that increase intracellular $\mathrm{Ca}$ relative to intracellular $\mathrm{Mg}$. Our previously published data using the CT26 model of colon cancer revealed that mice fed a $\mathrm{MgD}$ diet had larger tumors than mice fed the $100 \% \mathrm{Mg}$ diet [65]. We were unable to elucidate the molecular mechanisms due to limited tumor tissue available for analysis; in hindsight it is possible that the aneuploid cell population in the tumor proliferated more with sustained, elevated intracellular Ca with the MgD diet, as compared to the diploid cell population.

In conclusion, we show for the first time that $\mathrm{MgD}$ (with high Ca:Mg ratios) promotes oxidative stress and increases cell migration using CT26 colon cancer cells. We propose that MgD exposure (with high Ca: $\mathrm{Mg}$ ratios) increases intracellular $\mathrm{Ca}$ levels in part by increasing TRPM7 expression and unblocking the gating effect of $\mathrm{Mg}$ on intracellular $\mathrm{Ca}$ entry. Increased intracellular $\mathrm{Ca}$ levels promote ROS generation and $\mathrm{MgD}$ likely blunts cell-associated antioxidant capacity to further promote oxidative stress. We further show that high intracellular $\mathrm{Ca}$ levels and elevated oxidative stress: 1) activate calpain signaling leading to downstream activation of E-cadherin, FAK, $\mathrm{p} 53, \mathrm{NF}-\mathrm{\kappa B}$, and $\beta$-catenin signaling pathways and 2) lead to p53 loss and genomic instability, which in combination promote an aggressive and metastatic phenotype (figure 5). This study also sheds some insight on the epidemiological findings that link high $\mathrm{Ca}: \mathrm{Mg}$ ratios with increased incidence of cancer $[15,17$ 19, 32, 33] and increased mortality among colon cancer patients $[15,16]$. Finally, it provides a potential mechanism to explain prior studies reporting increased metastasis and higher mortality among tumor-bearing mice fed an $\mathrm{MgD}$ diet vs. tumor-bearing mice fed a $100 \% \mathrm{Mg}$ diet [45]. Future studies should further explore the roles of $\mathrm{Mg}$ status and $\mathrm{Ca}$ : $\mathrm{Mg}$ ratios using additional tumor cell lines and primary colon epithelial cells, more closely assess serum $\mathrm{Ca}: \mathrm{Mg}$ ratios among patients with cancer, including colon cancer, and investigate $\mathrm{Ca}: \mathrm{Mg}$ ratios in animal models of cancer and tumor metastasis.

\section{Acknowledgements}

The authors have no conflicts of interest to disclose. The authors wish to thank the Elmezzi Graduate School of Molecular Medicine at Northwell Health for supporting Dr. Gopal Kumar throughout his graduate studies. In addition, they wish to thank Dr. Robert Baker (gastroenterologist) and Mr. Chander Iyer (AWSM Scientific Achievement Award to CNM) for their financial support. Also, special thanks to Dr. Philippe Marambaud for allowing the authors to use his fluorescence plate reader for the assessment of calpain activity.

\section{References}

1. Jahnen-Dechent W, Ketteler M. Magnesium basics. Clin Kidney J 2012; 5 : i3-14.

2. Williams RJ. Calcium. Methods Mol Biol 2002; 172 : 21-49.

3. Robert JP, Williams RR. Evolution's Destiny. United Kingdom: Royal Society of Chemistry.

4. Long S, Romani AM. Role of cellular magnesium in human diseases. Austin J Nutr Food Sci 2014; 2 : 1051.

5. Wolf FI, Trapani V. Cell (patho)physiology of magnesium. Clin Sci 2008; 114 : 27-35.

6. Iseri LT, French JH. Magnesium: nature's physiologic calcium blocker. Am Heart J 1984; 108 : 18893.

7. Wolf FI, Trapani V. Magnesium and its transporters in cancer: a novel paradigm in tumour development. Clin Sci 2012; 123 : 417-27.

8. Ford ES, Mokdad AH. Dietary magnesium intake in a national sample of U.S. adults. J Nutr 2003; 133 : 2879-82.

9. Rude RK. Magnesium deficiency: a cause of heterogenous disease in humans. J Bone Miner Res 1998; 13 : 749-58.

10. Castiglioni S, Maier JA. Magnesium and cancer: a dangerous liason. Magnes Res 2011; 24 : S92-100.

11. Berridge MJ. Calcium signal transduction and cellular control mechanisms. Biochim Biophys Acta 2004; 1742 : 3-7.

12. Hanahan D, Weinberg RA. The hallmarks of cancer. Cell 2000; $100: 57-70$.

13. GBD 2015 Mortality, Causes of Death Collaborators. . Global, regional, and national life expectancy, all-cause mortality, and cause-specific mortality for 249 causes of death, 1980-2015: a 
systematic analysis for the Global Burden of Disease Study 2015. Lancet 2016; 388 : 1459-544.

14. Siegel RL, Miller KD, Jemal A. Cancer statistics, 2020. CA Cancer J Clin 2020; 70 : 7-30.

15. Dai Q, Shrubsole MJ, Ness RM, et al. The relation of magnesium and calcium intakes and a genetic polymorphism in the magnesium transporter to colorectal neoplasia risk. Am J Clin Nutr 2007; 86 : 743-51.

16. Dai Q, Shu X-O, Deng X, et al. Modifying effect of calcium/magnesium intake ratio and mortality: a population-based cohort study. BMJ Open 2013; 3 : e002111.

17. Sun Y, Selvaraj S, Varma A, Derry S, Sahmoun AE, Singh BB. Increase in serum $\mathrm{Ca} 2+/ \mathrm{Mg} 2+$ ratio promotes proliferation of prostate cancer cells by activating TRPM7 channels. J Biol Chem 2013; 288 : 255-63.

18. Omofuma O, Arab L, Su LJ, et al. Calcium to magnesium intake ratio and prostate cancer aggressiveness. FASEB J 2017; 31 : 790.733790.733

19. Steck SE, Omofuma OO, Su LJ, et al. Calcium, magnesium, and whole-milk intakes and highaggressive prostate cancer in the North CarolinaLouisiana Prostate Cancer Project (PCaP). Am J Clin Nutr 2018; 107 : 799-807.

20. Tao M-H, Dai Q, Millen AE, et al. Associations of intakes of magnesium and calcium and survival among women with breast cancer: results from Western New York Exposures and Breast Cancer (WEB) Study. Am J Cancer Res 2015; 6 : 105-13.

21. Bailey RL, Dodd KW, Goldman JA, et al. Estimation of total usual calcium and vitamin D intakes in the United States. J Nutr 2010; 140 : 817-22.

22. Sun L, Kosugi Y, Kawakami E. Magnesium concentration in the cerebrospinal fluid of mice and its response to changes in serum magnesium concentration. Magnes Res 2009; 22 : 266-72.

23. Eruslanov E, Kusmartsev S. Identification of ROS using oxidized DCFDA and flow-cytometry. Methods Mol Biol 2010; 594 : 57-72.

24. Rose AH, Huang Z, Mafnas C, et al. Calpain-2 inhibitor therapy reduces murine colitis and colitis-associated cancer. Inflamm Bowel Dis $2015 ; 21: 2005-15$.

25. Venter C, Niesler C. Rapid quantification of cellular proliferation and migration using ImageJ. BioTechniques 2019; 66 : 99-102.

26. Carbonari M. New use for an old reagent: cell cycle analysis of DNA content using flow cytometry in formamide treated cells. Cytometry 2016; 89 : 498503.
27. Wang J, Liao QJ, Zhang Y, et al. TRPM7 is required for ovarian cancer cell growth, migration and invasion. Biochem Biophys Res Commun 2014; 454 : 547-53.

28. Chan KT, Bennin DA, Huttenlocher A. Regulation of adhesion dynamics by calpain-mediated proteolysis of focal adhesion kinase (FAK). J Biol Chem $2010 ; 285$ : 11418-26.

29. Kubbutat MH, Vousden KH. Proteolytic cleavage of human p53 by calpain: a potential regulator of protein stability. Mol Cell Biol 1997; $17: 460-8$

30. Lad SP, Li J, da Silva Correia J, et al. Cleavage of p65/RelA of the NF-kappaB pathway by Chlamydia. Proc Natl Acad Sci U S A 2007; 104 : 2933-8.

31. Bhattacharya RK. Does widespread calcium supplementation pose cardiovascular risk? No: concerns are unwarranted. Am Fam Physician 2013; 87: Online.

32. Sahmoun AE, Singh BB. Does a higher ratio of serum calcium to magnesium increase the risk for postmenopausal breast cancer? Med Hypotheses 2010; $75: 315-8$.

33. Dai Q, Motley SS, Smith JA, et al. Blood magnesium, and the interaction with calcium, on the risk of high-grade prostate cancer. PLoS One 2011; 6 : e18237.

34. Zheltova AA, Kharitonova MV, Iezhitsa IN, Spasov AA. Magnesium deficiency and oxidative stress: an update. Biomedicine (Taipei) 2016; 6 : 20.

35. Clapham DE. TRP channels as cellular sensors. Nature 2003; 426 : 517-24.

36. Freichel M, Flockerzi V. Biological functions of TRPs unravelled by spontaneous mutations and transgenic animals. Biochem Soc Trans 2007; 35 : 120-3.

37. Trapani V, Wolf FI. The TRPM7 channel kinase: rekindling an old flame or not? Cardiovasc Res 2019; 116 : 476-8.

38. Romani AM. Cellular magnesium homeostasis. Arch Biochem Biophys 2011; 512 : 1-23.

39. Guilbert A, Gautier M, Dhennin-Duthille I, Haren N, Sevestre H, Ouadid-Ahidouch H. Evidence that TRPM7 is required for breast cancer cell proliferation. Am J Physiol Cell Physiol 2009; 297 : C493502 .

40. Julianna Maria Santos FH. Magnesium chloride is an effective therapeutic agent for prostate cancer. FFHD 2018; $8: 62-8$.

41. Baldoli E, Maier JA. Silencing TRPM7 mimics the effects of magnesium deficiency in human microvascular endothelial cells. Angiogenesis 2012; 15 : 47-57. 
42. Zhang B, Wang Y, Su Y. Peroxiredoxins, a novel target in cancer radiotherapy. Cancer Lett 2009; 286 : 154-60.

43. Castle JC, Loewer M, Boegel S, et al. Immunomic, genomic and transcriptomic characterization of CT26 colorectal carcinoma. BMC Genomics 2014; $15: 190$.

44. Tsai FC, Kuo GH, Chang SW, Tsai PJ. Ca2+ signaling in cytoskeletal reorganization, cell migration, and cancer metastasis. BioMed Res Int 2015; 2015 : 409245.

45. Nasulewicz A, Wietrzyk J, Wolf FI, et al. Magnesium deficiency inhibits primary tumor growth but favors metastasis in mice. Biochim Biophys Acta 2004; 1739 : 26-32.

46. Jacques-Fricke BT, Seow Y, Gottlieb PA, Sachs F, Gomez TM. Ca2+ influx through mechanosensitive channels inhibits neurite outgrowth in opposition to other influx pathways and release from intracellular stores. J Neurosci 2006; 26 : 5656-64.

47. Kimura Y, Saya H, Nakao M. Calpain-dependent proteolysis of NF2 protein: involvement in schwannomas and meningiomas. Neuropathology 2000; 20 : 153-60.

48. Lakshmikuttyamma A, Selvakumar P, Kanthan R, Kanthan SC, Sharma RK. Overexpression of mcalpain in human colorectal adenocarcinomas. Cancer Epidemiol Biomarkers Prev 2004; 13 : 1604-9.

49. Storr SJ, Carragher NO, Frame MC, Parr T, Martin SG. The calpain system and cancer. Nat Rev Cancer 2011; 11 : 364.

50. McLean GW, Carragher NO, Avizienyte E, Evans J, Brunton VG, Frame MC. The role of focaladhesion kinase in cancer - a new therapeutic opportunity. Nat Rev Cancer 2005; 5 : 505-15.

51. Tai YL, Chen LC, Shen TL. Emerging roles of focal adhesion kinase in cancer. BioMed research international 2015; 2015 : 690690.

52. Zhao X, Guan JL. Focal adhesion kinase and its signaling pathways in cell migration and angiogenesis. Adv Drug Deliv Rev 2011; 63 : 610-5.

53. Jacamo RO, Rozengurt E. A truncated FAK lacking the FERM domain displays high catalytic activity but retains responsiveness to adhesionmediated signals. Biochem Biophys Res Commun 2005; 334 : 1299-304.
54. Lim JA, Hwang SH, Kim MJ, Kim SS, Kim HS. Nterminal cleavage fragment of focal adhesion kinase is required to activate the survival signalling pathway in cultured myoblasts under oxidative stress. FEBS $J$ 2012; 279 : 3573-83.

55. Xia Y, Shen S, Verma IM. NF-kappaB, an active player in human cancers. Cancer Immunol Res 2014; 2 : 823-30.

56. Liu TL, Shimada H, Ochiai T, et al. Enhancement of chemosensitivity toward peplomycin by calpastatin-stabilized NF-kappaB p65 in esophageal carcinoma cells: possible involvement of Fas/FasL synergism. Apoptosis 2006; 11 : 1025-37.

57. Reijonen S, Kukkonen JP, Hyrskyluoto A, et al. Downregulation of NF-kappaB signaling by mutant huntingtin proteins induces oxidative stress and cell death. Cell Mol Life Sci 2010; 67 : 1929-41.

58. Berx G, van Roy F. Involvement of members of the cadherin superfamily in cancer. Cold Spring Harbor Perspect Biol 2009; 1 : a003129.

59. Birchmeier W, Behrens J. Cadherin expression in carcinomas: role in the formation of cell junctions and the prevention of invasiveness. Biochim Biophys Acta 1994; 1198 : 11-26.

60. Christou N, Perraud A, Blondy S, Jauberteau MO, Battu S, Mathonnet M. E-cadherin: a potential biomarker of colorectal cancer prognosis. Oncol Lett 2017; 13 : 4571-6.

61. Rios-Doria J, Day KC, Kuefer R, et al. The role of calpain in the proteolytic cleavage of E-cadherin in prostate and mammary epithelial cells. $J$ Biol Chem 2003; 278 : 1372-9.

62. Yap AS, Brieher WM, Gumbiner BM. Molecular and functional analysis of cadherin-based adherens junctions. Annu Rev Cell Dev Biol 1997; 13 : 119-46.

63. Harper JW, Adami GR, Wei N, Keyomarsi K, Elledge SJ. The p21 Cdk-interacting protein Cip1 is a potent inhibitor of G1 cyclin-dependent kinases. Cell 1993; 75 : 805-16.

64. Jackson SP, Bartek J. The DNA-damage response in human biology and disease. Nature 2009; 461 : 1071-8.

65. Kumar G, Solanki MH, Xue X, et al. Magnesium improves cisplatin-mediated tumor killing while protecting against cisplatin-induced nephrotoxicity. Am J Physiol Renal Physiol 2017; 313 : F339-50. 